\title{
Parkinsonism as presenting symptom of primary hyperparathyroidism: Improvement after surgery
}

Parkinsonismo como síntoma principal de hiperparatiroidismo: recuperación tras cirugía

Delia Luján-Martínez*, Ángela Sánchez-Cifuentes, Emilio Peña-Ros, Antonio Albarracín-Marín-Blázquez and Mari Fe Candel-Arenas

Department of General and Digestive System Surgery, Hospital General Universitario Reina Sofía, Murcia, Spain

\begin{abstract}
Introduction: Hypercalcemia can cause different neurological disorders, depending on the calcium level. We report an exceptional case of primary hyperparathyroidism presenting as neurological alteration and it has favourable outcome after parathyroidectomy. Case report: A 74-year-old woman presented with progressive cognitive deterioration and impaired motor function. The complementary tests showed hypercalcemia due to a parathyroid adenoma. Parathyroidectomy was performed with symptomatic improvement. Conclusion: Cognitive impairment of the elderly due to a parathyroid adenoma is underdiagnosed, behavioral changes and alterations of motor functions are attributed to age, dementia and frailty, representing a diagnostic challenge.
\end{abstract}

KEY WORDS: Parkinsonism. Primary hyperparathyroidism. Hypercalcemia

\section{Resumen}

Introducción: La hipercalcemia puede causar diferentes trastornos neurológicos, dependiendo de las concentraciones de calcio. Aportamos un caso excepcional de hiperparatiroidismo primario que se manifestó con deterioro neurológico rápidamente evolutivo y se resolvió mediante paratiroidectomía. Caso clínico: Mujer de 74 años que consultó por deterioro cognitivo progresivo y alteración de las funciones motoras. Las pruebas complementarias evidenciaron hipercalcemia debida a un adenoma paratiroideo. Se realizó paratiroidectomía, con mejoría sintomática. Conclusión: El deterioro cognitivo del anciano por un adenoma paratiroideo está infradiagnosticado, pues los cambios de conducta y las alteraciones de las funciones motoras se atribuyen a la edad, la demencia y la fragilidad, suponiendo un reto diagnóstico.

PALABRAS CLAVE: Parkinsonismo. Hiperparatiroidismo primario. Hipercalcemia.

\section{Correspondence:}

*Delia Luján-Martínez

Avenida Intendente Jorge Palacios 1

C.P. 30003, Murcia, España

E-mail: deliamaria.lujan@gmail.com
Date of reception: 17-01-2018

Date of acceptance: 14-02-2018

DOI: $10.24875 /$ CIRUE.M18000015
Cir Cir. 2018;86:96-98

Contents available at PubMed www.cirugiaycirujanos.com 


\section{Introduction}

Clinical manifestations of primary hyperparathyroidism (PHPT) are associated with excess of circulating parathyroid hormone (PTH) and hypercalcemia. High calcium levels can cause different neurological disorders ${ }^{1}$. We present an exceptional case of PHPT that had an onset with rapidly evolving Parkinsonism and was resolved after parathyroidectomy.

\section{Clinical case}

A 74-year-old woman with a history of hypertension, dyslipidemia, intrinsic asthma and hysterectomy, sought medical attention for progressive cognitive impairment with motor function alteration, partial disorientation, bradypsychia, and rapid onset gait abnormality, all of these symptoms suggestive of Parkinsonism.

Brain MRI (Fig. 1) revealed chronic small vessel ischemic lesions, index 10 Parkinsonism, not suggestive of progressive supranuclear palsy. Laboratory tests showed calcium $14 \mathrm{mg} / \mathrm{dL}$, phosphorus $2.1 \mathrm{mg} / \mathrm{dL}$, PTH $483 \mathrm{pg} / \mathrm{mL}$, normal tumor markers and renal function without alterations. Cervical ultrasound (Fig. 2) reported an enlarged thyroid gland with bilateral nodules of up to $11 \mathrm{~mm}$ and, adjacent to the lower pole of the left thyroid lobe, a well-defined, hypoechoic and homogeneous nodule with a size of about $10 \mathrm{~mm}$ of probable parathyroid origin was observed.

Treatment was started with zoledronic acid and, after analytical parameters normalization, the patient showed symptom improvement, walking without support, with agile gait and without tremor, with recovery of her baseline state. An elective intervention was practiced, with a right thyroid nodule and a right inferior parathyroid adenoma being found. Hemithyroidectomy and parathyroidectomy were carried out, intraoperatively verifying a PTH decrease and performing histopathological examination of parathyroid tissue.

Pathological anatomy analysis reported a $3.27-\mathrm{g}$ parathyroid adenoma and hemithyroid gland with colloid nodule. The patient is currently asymptomatic, with normal calcium and PTH.

\section{Discussion}

PHPT is an endocrine disorder that mainly affects postmenopausal women by altering the phosphocalcic metabolism. These patients usually present with nephrolithiasis, osteitis fibrosa cystica or recurrent renal

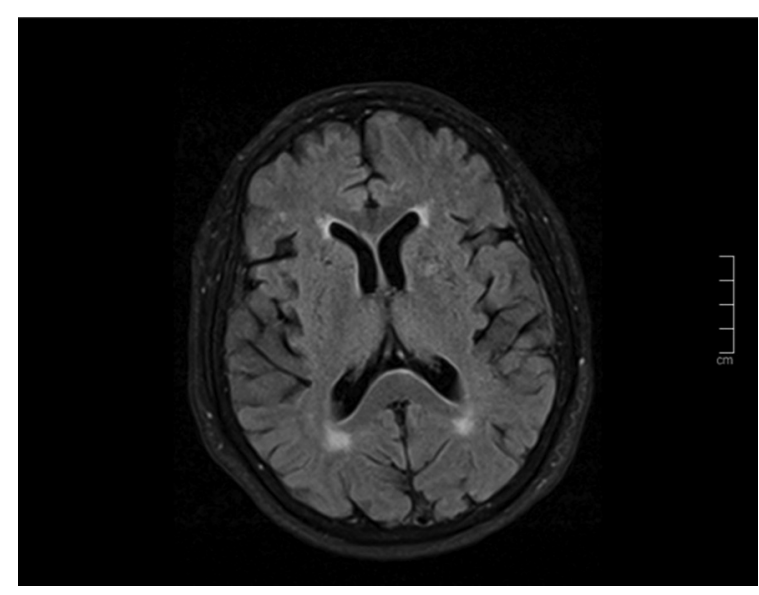

Figure 1. Brain MRI showing small vessel ischemic lesions.

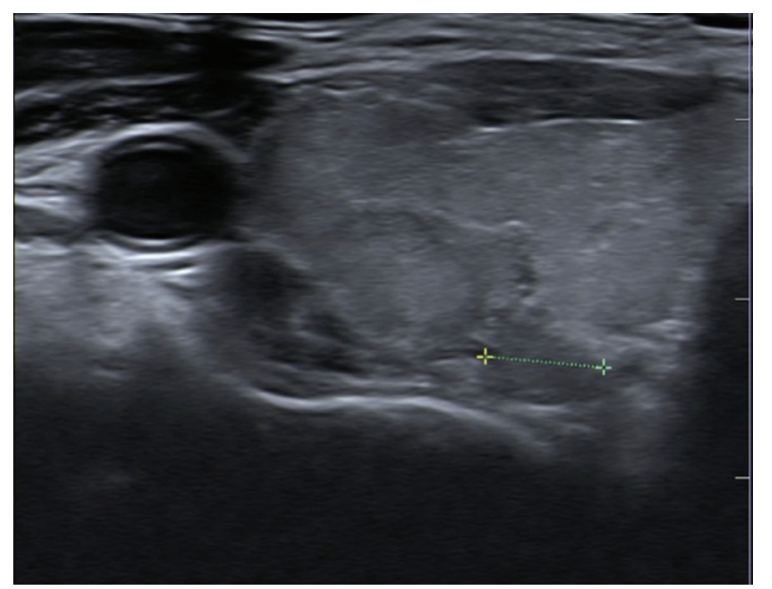

Figure 2. Cervical ultrasound, where left hemithyroid gland is visualized with several nodules and, adjacent to the inferior lobe, a well-delimited, hypoechoic and homogeneous nodule, of about $10 \mathrm{~mm}$ and probable parathyroid origin.

lithiasis, all of them absent in our patient ${ }^{2}$. Parkinsonism as a symptom of PHPT presentation is extremely rare, with very few cases described in the literature ${ }^{3-5}$.

Calcium-PTH homeostasis alteration can be a risk factor or an aggravating factor for the development of Parkinsonism. Calcium is necessary for the regulation of neuromuscular membrane excitability and neurotransmitter release. Elevated calcium concentrations can influence on dopamine receptor structure and function, thereby interrupting neuronal signaling ${ }^{1,5}$.

Global cognitive deterioration in the elderly due to a parathyroid adenoma is underdiagnosed. Behavioral changes and alterations in motor functions are usually attributed to age, dementia and frailty, thus entailing a diagnostic challenge. Therefore, these patients can benefit from medical-surgical treatment, as in the case of our patient, who exhibited a remarkable recovery of all cognitive and motor functions after hypercalcemia correction and parathyroidectomy. 


\section{Ethical responsibilities}

Protection of people and animals. The authors declare that no experiments on humans or animals have been conducted for this research.

Confidentiality of data. The authors declare to have followed the protocols of their work center on the publication of patient data.

Right to privacy and informed consent. The authors have obtained informed consent from the patients and/or subjects referred to in the article. This document is in possession of the corresponding author.

\section{Funding}

The authors declare there was no external financing.

\section{Conflict of interests}

The authors declare there are no conflicts of interest.

\section{References}

1. Lourida I, Thompson-Coon J, Dickens CM, Soni M, Kuźma E, Kos K et al. Parathyroid hormone, cognitive function and dementia: a systematic review. PLoS One. 2015;10:e0127574.

2. Bandeira L, Bilezikian J. Primary hyperparathyroidism. F1000 Research. 2016;5:F1000 Faculty Rev-1.

3. Hirooka Y, Yuasa K, Hibi K, Ishikawa A, Sobue G, Naruse T, et al. Hyperparathyroidism associated with parkinsonism. Intern Med. 1992;31:904-7.

4. Kovacs CS, Howse DC, Yendt ER. Reversible parkinsonism induced by hypercalcemia and primary hyperparathyroidism. Arch Intern Med. 1993;153:1134-6.

5. De Rosa A, Rinaldi C, Tucci T, Pappata S, Rossi F, Morra VB, et al. Co-existence of primary hyperparathyroidism and Parkinson's disease in three patients: an incidental finding? Parkinsonism Relat Disord. 2011:17:771-3. 